\title{
THE EFFECT OF HIGH PROTEIN DIETS ON THE REMAIN- ING KIDNEY OF RATS
}

BY HENRY JACKSON, JR., AND OLIVE J. MOORE

(From the Thorndike Memorial Laboratory, Boston City Hospital, and the Medical Service of the Collis P. Huntington Memorial Hospital, Harvand University, Boston)

(Received for publication December 27, 1927)

In recent years much interest has attached to the rôle of high protein diets in the production of renal lesions. Newburgh (1) found varying degrees of tubular injury in rabbits fed egg white, casein or soy bean, but he describes no glomerular lesions. Squiers and Newburgh (2) found albumin and casts and red cells in the urine of hypertensive patients after feeding high protein diets. Newburgh and Clarkson (3) described dilatation of the tubules and some slight scarring of the glomeruli in rabbits after feeding 37 per cent lean beef for 6 to 12 months. In 1923 Polvogt (4) found degeneration of the tubules and some glomerular damage in rats on diets containing 31 to 41 per cent protein. Evans (5) produced both glomerular and tubular damage in rats with high protein diets but the diet was deficient in both vitamins and salts. Osborne and Mendel (5) describe tubular and glomerular lesions in high protein rats but the lesions were very slight except for a few animals over 400 days old, and furthermore similar lesions were found in animals of the same age on low protein stock diets. They do not claim to have produced nephritis.

On the other hand, Osborne (7), Drummond (8), Reeder (9), Miller (10), Jackson (11), Addis (12), and Kennedy (13) have all failed to produce significant renal lesions by feeding large amounts of protein to intact animals over a considerable period of time.

Moise and Smith (18) report their findings on 200 rats, from which one kidney was removed prior to their being put on high protein diet. The animals were 120 days old at the start of the experiment. The diet contained 85 per cent casein and was otherwise adequate for growth. The experimental period lasted from 3 to 150 days. They report that after 90 days all the animals showed significant changes 
in both the glomeruli and the tubules. There was proliferation of the Bowman's capsule, serum in the capsular spaces, adhesions between the capsule and the tuft, and occasionally hyaline casts in the often dilated and degenerated tubules. They found further that the rats on normal diets excreted from 18 to $35 \mathrm{mgm}$. albumin in the urine a day, while those on high protein diets excreted from 30 to $63 \mathrm{mgm}$. a day. They suggest that much of the previous difference of opinions between various authors could be explained on the variable age of the animals used, as they find that the younger animals are more resistant to the toxic action of dietary protein than older ones.

In this paper we wish briefly to report the findings in a series of white rats kept on a diet containing 76 per cent casein for periods of from 2 to 17 months after the removal of one kidney. The series is admittedly small. Eighteen rats from 2 to 8 months old had one kidney removed and were then placed on adequate diets containing 76 per cent casein and described in a previous paper (11). Two rats as controls were placed after nephrectomy on standard diets containing 18 per cent casein. At intervals the various rats were placed in individual metabolism cages and their urine examined for albumin and casts. The animals' weight was periodically recorded. At the end of the experimental period they were killed, the organs were fixed in Zenker's solution and stained with eosin methylene blue. Blood was collected at the termination of the experiment and the nonprotein nitrogen determined. Eleven of the rats were on a high protein diet for a year or more, yet the degree of renal damage could not be entirely satisfactorily correlated with either the age of the rat or the duration of the experiment. Rats 1, 2, 3 and 4 showed by far the most serious lesions. In all of these were found marked dilatation of the tubules throughout the kidney substance with flattening of the lining epithelium, moderate to severe fibrosis of practically all of the glomeruli with hyaline changes and occasionally vacuolization within the tuft, and scattered areas of tubular damage with subsequent cellular regeneration. In a few places hyaline deposits were found in the tubular epithelium. The glomeruli were often adherent to the capsule. Casts were present in great numbers. The glomeruli were often nearly devoid of blood cells. Pigment was found frequently in the tubules and occasionally in the interstitial tissue. Round cell 
infiltration was common. On the other hand, rat 8 was on the diet longest (17 months) yet showed very few renal lesions.

The non-protein nitrogen of the blood in the 18 rats on high protein varied from 40 to $160 \mathrm{mgm}$. per $100 \mathrm{ml}$. In but 2, however, was it above $55 \mathrm{mgm}$.- a figure often equalled and sometimes surpassed in animals with intact kidneys on a 76 per cent casein diet (11). Rats

TABLE 1

\begin{tabular}{|c|c|c|c|c|c|c|c|c|c|c|}
\hline 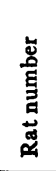 & 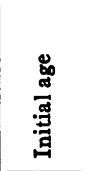 & 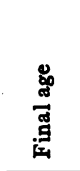 & 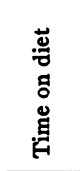 & 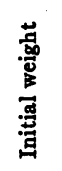 & 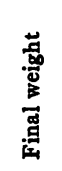 & 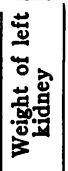 & 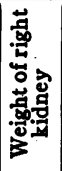 & 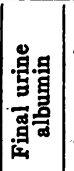 & 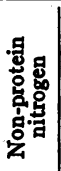 & Remarks \\
\hline & months & months & months & & & & & & & \\
\hline 1 & 6 & 20 & 14 & 337 & 337 & 1.4 & 2.8 & 591 & 55 & Marked renal damage \\
\hline 2 & 7 & 20 & 13 & 370 & 347 & 1.6 & 2.9 & 370 & 49 & Marked renal damage \\
\hline 3 & 7 & 20 & 13 & 396 & 290 & 1.6 & 4.3 & 450 & 160 & Marked renal damage \\
\hline 4 & 6 & 16 & 10 & 232 & 210 & 0.8 & 2.6 & 155 & 80 & Marked renal damage \\
\hline 5 & 6 & 14 & 8 & 253 & 247 & 0.8 & 1.9 & 33 & 50 & Very slight changes \\
\hline 6 & 8 & 23 & 15 & 379 & 370 & 1.8 & 3.2 & 40 & 54 & \\
\hline 7 & 6 & 14 & 8 & 342 & 349 & 0.9 & 2.2 & 42 & 51 & \\
\hline 8 & 8 & 23 & 17 & 347 & 427 & 1.0 & 3.3 & 44 & 46 & Very slight damage \\
\hline 9 & 6 & 10 & 4 & 257 & 257 & 0.9 & 1.8 & 6 & 49 & No casts \\
\hline 10 & 6 & 11 & $\mathbf{5}$ & 227 & 229 & 0.7 & 1.6 & 6 & 47 & No casts \\
\hline 11 & 4 & 17 & 13 & 259 & 319 & 0.7 & 1.8 & 46 & 44 & \\
\hline 12 & 5 & 19 & 14 & 240 & 241 & 0.9 & 1.8 & 94 & 43 & \\
\hline 13 & 4 & 17 & 13 & 170 & 190 & 0.7 & 1.5 & 38 & 51 & \\
\hline 14 & 3 & 16 & 13 & 252 & 245 & 0.9 & 1.8 & 150 & 49 & No apparent damage \\
\hline 15 & 2 & 13 & 11 & 130 & 231 & 0.9 & 1.7 & 8 & 40 & \\
\hline 16 & 3 & 15 & 12 & 169 & 242 & 0.8 & $2: 8$ & 124 & 50 & \\
\hline 17 & 3 & 16 & 13 & 140 & 230 & 1.3 & 3.0 & $42 \mid$ & 46 & \\
\hline 18 & 6 & 8 & 2 & 255 & 240 & 1.1 & 1.2 & 6 & 40 & No casts \\
\hline $19^{*}$ & 6 & 23 & 17 & 242 & 319 & 0.9 & 1.8 & 16 & 33 & No casts \\
\hline $20^{*}$ & 6 & 23 & 17 & 255 & 280 & 1.0 & 1.8 & 16 & 36 & No casts \\
\hline
\end{tabular}

* Rats on standard diet of 18 per cent casein.

$5,7,8,9,14$ and 16 showed very few if any renal changes. Rats 6 , $10,11,12,13,15,17$ and 18 showed lesions similar to those in rats 1,2 , 3 and 4 , but of very much less extent. In fact, the glomerular lesions in these former rats might well be missed on casual observation whereas the picture in numbers 1, 2, 3 and 4 was that of an advanced chronic glomerular nephritis. In none of the animals did we find the exten- 
sion of the renal epithelium into the capsular space mentioned by Moise and Smith.

Though apparently healthy, a few of the rats lost weight. The majority showed increased urinary albumin, in one case as high as 591 $\mathrm{mgm}$. a day. Four rats showed no increase of urinary protein over the normal and of these three were on the experimental diet over 120 days. Nearly all animals showed casts. The average hypertrophy of the remaining kidney in the high protein group was 136 per cent. The average hypertrophy in the two standard diet rats was 100 per cent. As has been indicated, the extent of renal injury apparent at autopsy differed markedly from animal to animal. In some, the tubular damage was considerable while the glomerular damage was insignificant or wanting. In others, the lesion was mainly glomerular. In some, no lesion could be demonstrated other than an occasional dilatation of the tubules. It would seem that the tubular damage was the first to be produced and that the glomerular damage was a natural sequel or a later event. We can offer no more satisfactory explanation of these variations than age together with a varying individual susceptibility of the animals, and it is noteworthy that rats 1 to 4 inclusive came from a different stock from the rest of the animals. In general, however, we agree with Moise and Smith that age is an important factor.

The glomeruli seem to increase in size slightly above the normal but it would appear that the glomeruli also increase in size with partial nephrectomy and normal diet. The glomeruli of rats on high protein diets averaged $0.084 \mathrm{~mm}$. at the onset and 0.117 at the end of the experiment, an increase of 36.5 per cent. The glomeruli of rats on normal diets averaged $0.084 \mathrm{~mm}$. at the onset and $0.109 \mathrm{~mm}$. at the end of the experiment, an increase of 24.0 per cent.

That renal lesions have been produced is certain. The relation of the production of these lesions by such violently abnormal diets to the problem of human nephritis is quite another question. Severe nephritis was undoubtedly produced in four animals. In the remaining 14 the lesions were relatively insignificant yet these rats all excreted through their remaining kidney on the average 1.2 gram of nitrogen a day for about a third of their lifetime. For a healthy man of $70 \mathrm{kgm}$. with two kidneys to duplicate this experiment he would have to ingest approximately 44 pounds of meat a day for 20 years. 
Winter (14) reports an analysis of 237 cases of solitary kidney in man. Compensatory hypertrophy was almost always present. Of the 237 cases 171 were sound or merely enlarged. 21 had nephritis. Anders (15) found 16 cases of nephritis in 61 cases of single kidney. Manson (16) reports 3 cases of single kidney and in all 3 cases the remaining kidney was normal. Lyons (17) reports 2 cases with the remaining kidney normal. At the Boston City Hospital there have been 12 cases of congenital absence or congenital atrophy of one kidney. In 8 of these the remaining kidney was normal. In the remaining 4 there was some evidence of chronic nephritis, though in no case was the process the cause of death.

It would seem that nephritis is rather more liable to develop in single human kidneys than when both are present, and from the present work and that of Moise and Smith it would seem wise to avoid a large excess of dietary protein when one kidney is absent or markedly diseased.

\section{CONCLUSIONS}

Our experience with a small series of rats from which one kidney had been removed confirms the results of Moise and Smith in that a high dietary protein has produced at least some and often very severe damage to the remaining kidney.

We would agree with Moise and Smith that older animals are more liable to this damage but we feel that individual susceptibility is a very real factor in determining the degree of damage.

\section{BIBLIOGRAPHY}

1. Newburgh, L. H., Arch. Int. Med., 1919, xxiv, 359. The Production of Bright's Disease by Feeding High Protein Diets.

2. Squier, T. N., and Newburgh, L. H., Arch. Int. Med., 1921, xxviii, 1. Renal Irritation in Man from High Protein Diet.

3. Newburgh, L. H., and Clarkson, S., Arch. Int. Med., 1923, xxxii, 850. Renal Injury Produced in Rabbits by Diets Containing Meat.

4. Polvogt, L. M., McCollum, E. V., and Simmonds, N., Bull. Johns Hopkins Hosp., 1923, xxxiv, 168. The Production of Kidney Lesions in Rats by Diets Defective Only in that They Contained Excessive Amounts of Protein.

5. Evans, N., and Risley, E. H., Calif. and West. Med., 1925, xxiii, 437. High Protein Ration as a Cause of Nephritis. 
6. Osborne, T. B., Mendel, L. B., Park, E. A., and Winternitz, M. C., J. Biol. Chem., 1927, lxxi, 317. Physiological Effects of Diets Unusually Rich in Protein or Inorganic Salts.

7. Osborne, T. B., Mendel, L. B., Park, E. A., and Darrow, D., Proc. Soc. Exp. Biol. and Med., 1923, xx, 452. Kidney Hypertrophy Produced by Diets Unusually Rich in Protein.

8. Drummond, J. C., Crowden, G. P., and Hill, E. L. G., J. Physiol., 1922, lvi, 413. Nutrition on High Protein Dietaries.

9. Reader, V. B., and Drummond, J. C., J. Physiol., 1925, lix, 472. Further Observations on Nutrition with Diets Rich in Protein.

10. Miller, A. J., J. Exp. Med., 1925, xlii, 897. The Influence of High Protein Diet on the Kidneys.

11. Jackson, H., Jr., and Riggs, M. D., J. Biol. Chem., 1926, lxvii, 101. The Effect of High Protein Diets on the Kidney of Rats.

12. Addis, T., MacKay, E. M., and MacKay, L. N. J. Biol. Chem., 1926, lxxi, 139. The Effect on the Kidney of the Long Continued Administration of Diets Containing an Excess of Certain Food Elements.

13. Kennedy, W. P., Quart. J. Exp. Physiol., 1926, xvi, 281. Reproduction and Diet in the Rat.

14. Winter, G. J., Arch. f. Klin. Chir., 1903, lxix, 611. Ueber einseitige angeborene Nierendefecte, nebst einem Fall von nierencyste in der Solitärniere.

15. Anders, J. M., Am. J. Med. Sci., 1910, cxxxix, 313. Congenital Single Kidney, with the Report of a Case.

16. Manson, J. S., Brit. Med. J., 1907, ii, 1827. A Case of Single Kidney.

17. Lyon, M. W., J. A. M. A., 1916, lxvii, 1524. Two Cases of Congenital Absence of One Kidney.

18. Smith, A. H., and Moise, T. S., J. Exp. Med., 1927, xlv, 263. Diet and Tissue Growth; Rate of Compensatory Renal Enlargement after Unilateral Nephrectomy in White Rat. 


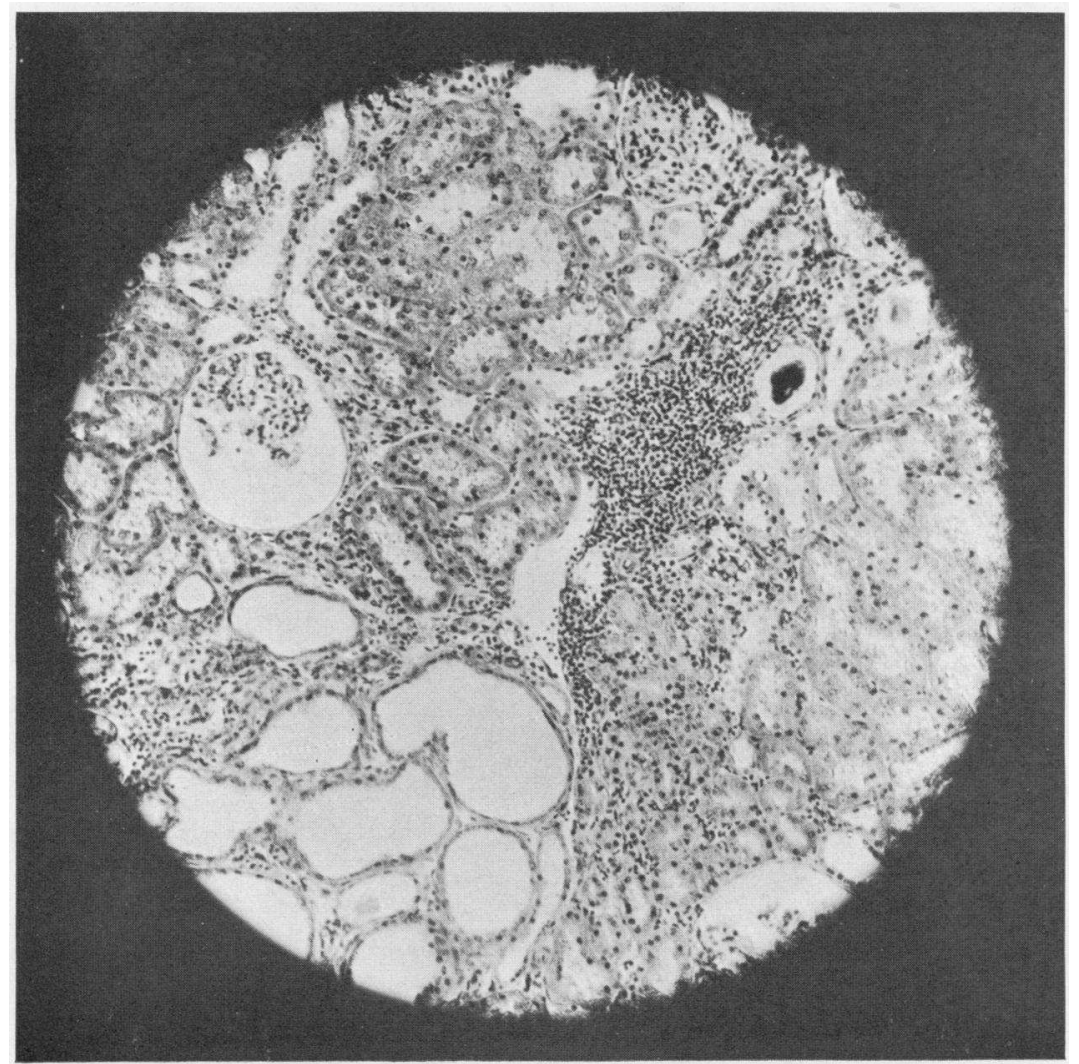

Fig. 1. Rat 2. Showing Dilatation of Tubules and Round Cell INFILTRATION. $\times 100$ 


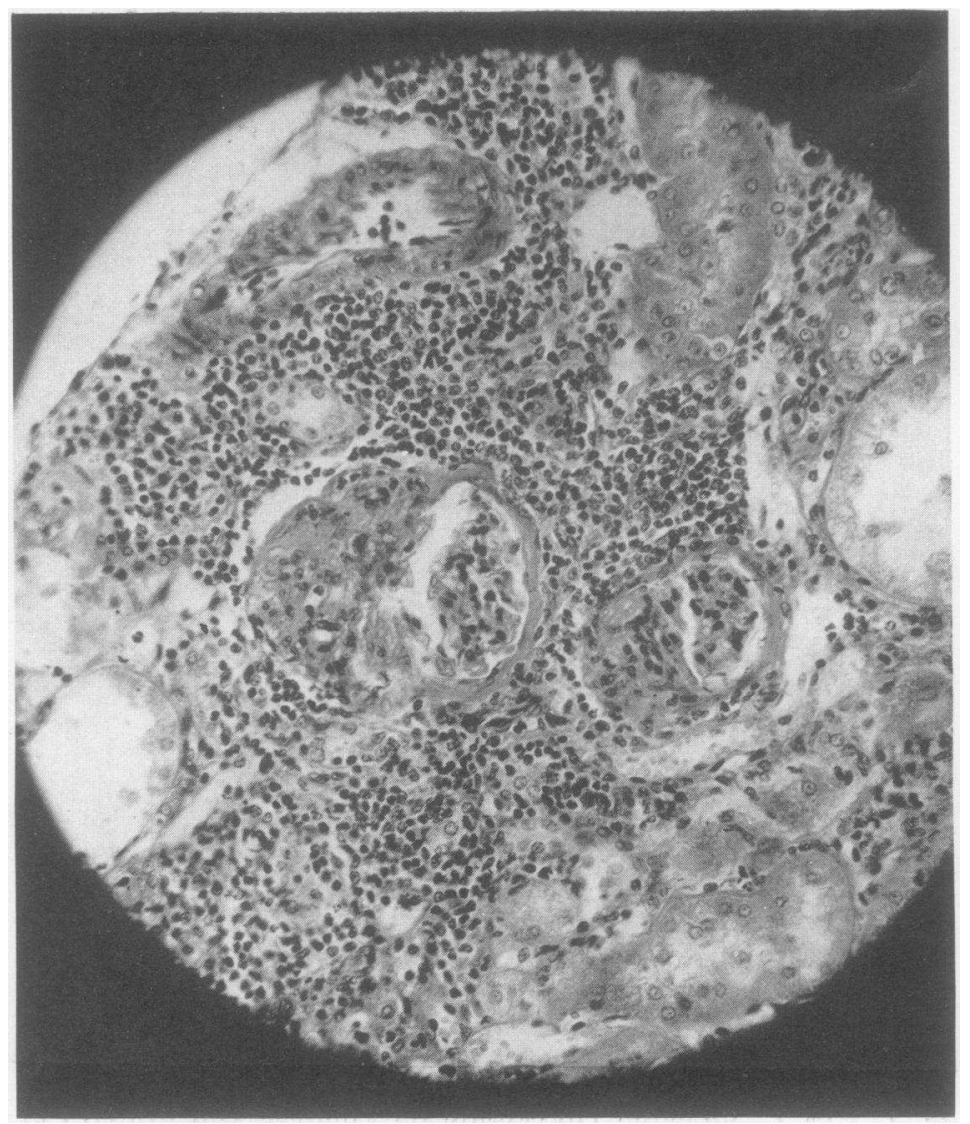

Fig. 2. Rat 1. Round Cell Infiltration and Fibrosis of Glomeruli 


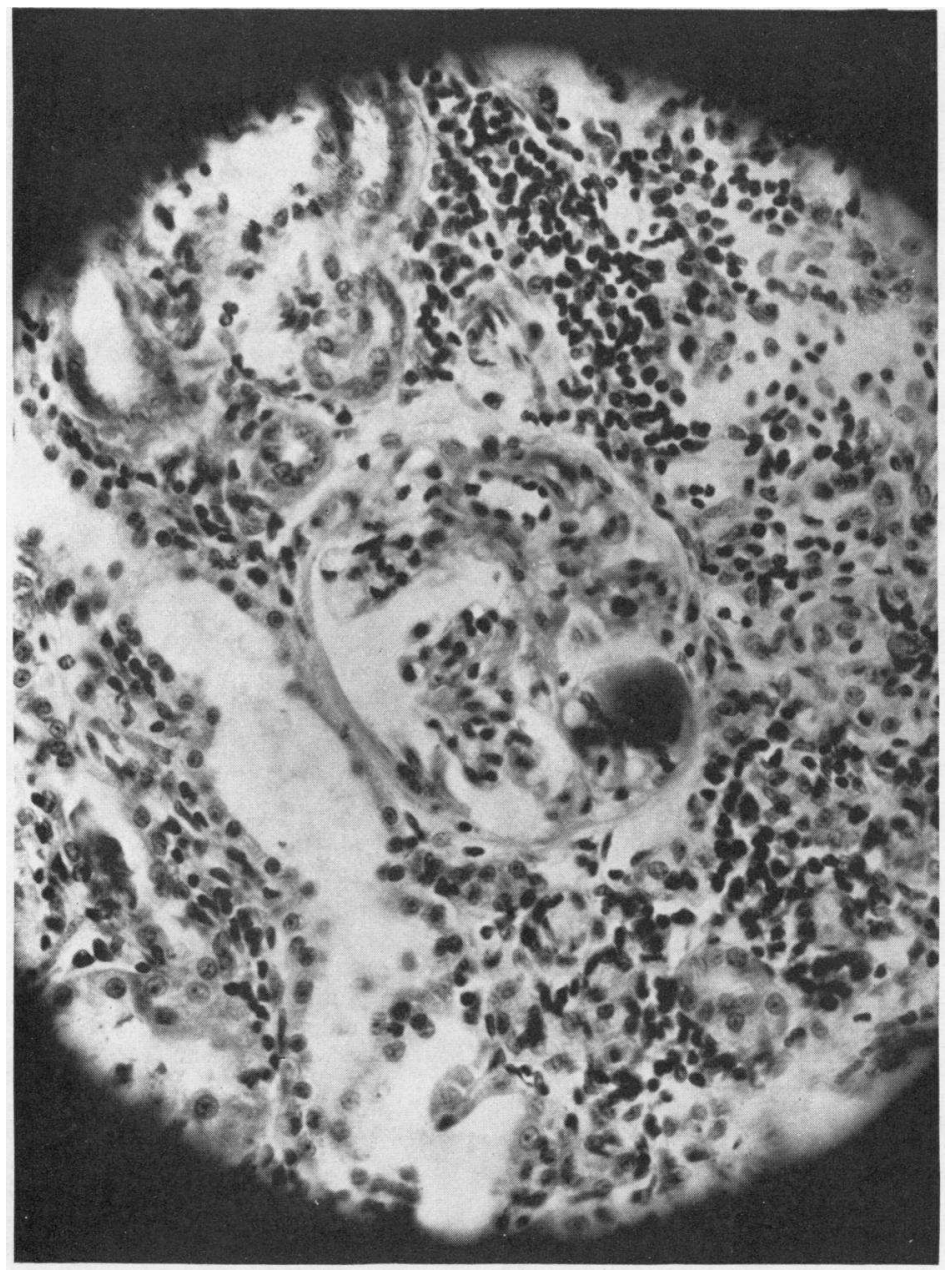

Fig. 3. Rat 2. Hyaline Deposit in Scarred Glomerulus. $\times 320$ 


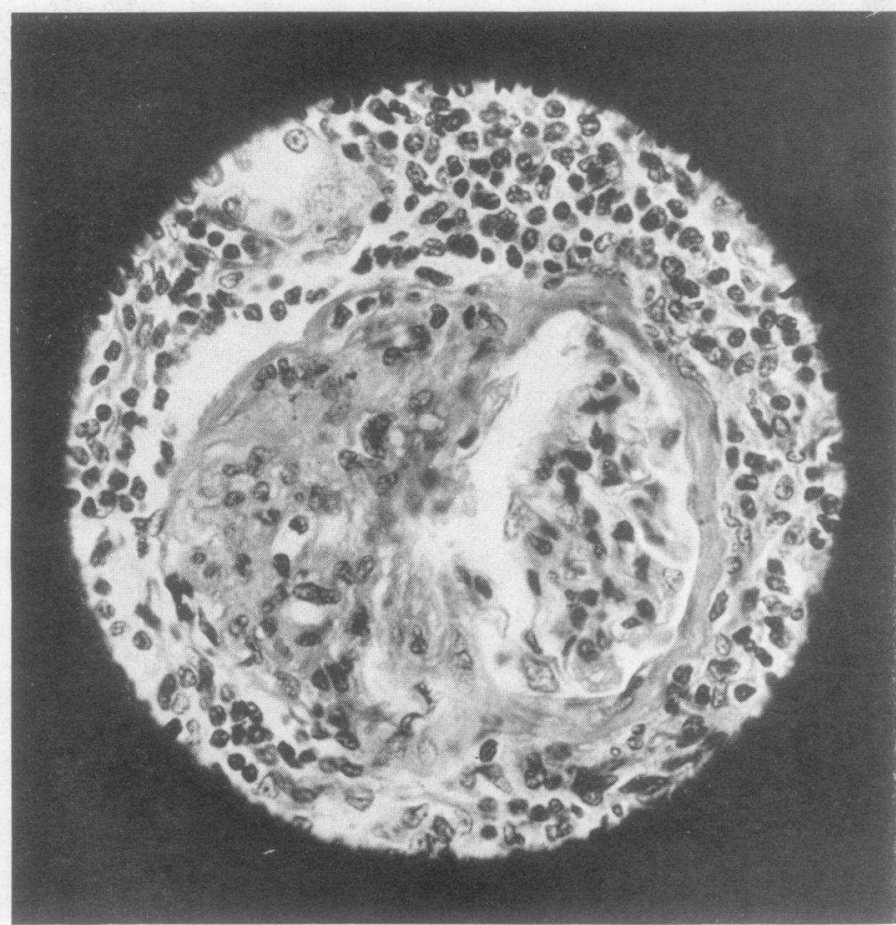

Fig. 4. Rat 10. Scarring of Glomerulus with Proliferative Capsular Changes. $\times 400$ 


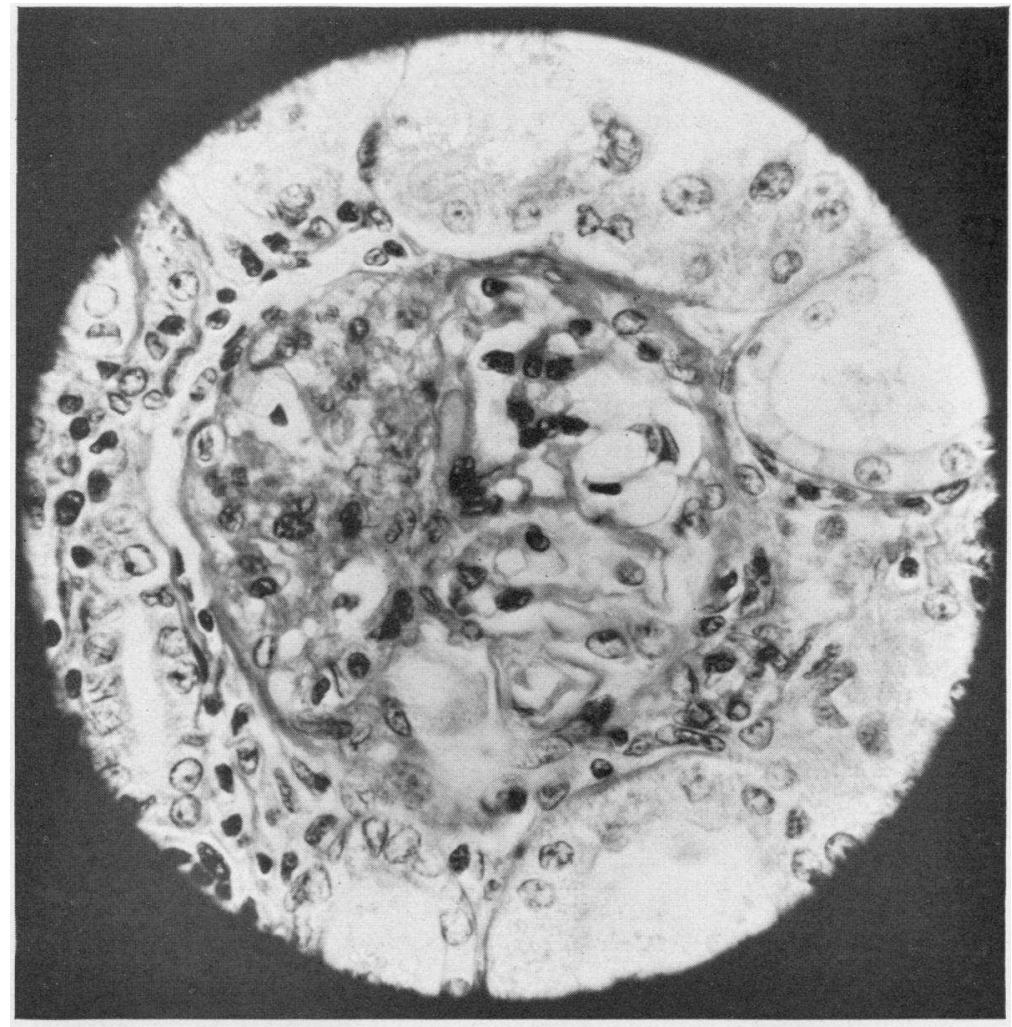

Fig. 5. Rat 6. Vacuolization Seen in Many Glomeruli. $\times 450$ 